\title{
Amyotrophic lateral sclerosis type 4
}

INSERM

\section{Source}

INSERM. (1999). Orphanet: an online rare disease and orphan drug data base.

Amyotrophic lateral sclerosis type 4. ORPHA:357043

\begin{abstract}
A rare, genetic motor neuron disease characterized by late childhood- or adolescentonset of slowly prog ressive, severe, distal limb muscle weakness and wasting, in association with pyramidal signs, normal sensation, and absence of bulbar involvement, leading to degeneration of motor neurons in the brain and spinal cord.
\end{abstract}

